\title{
Competition and R\&D cooperation with universities and competitors
}

\section{Journal Article}

Author(s):

Bolli, Thomas (D); Wörter, Martin (i)

Publication date:

2013-12

Permanent link:

https://doi.org/10.3929/ethz-b-000078854

Rights / license:

In Copyright - Non-Commercial Use Permitted

Originally published in:

The Journal of Technology Transfer 38(6), https://doi.org/10.1007/s10961-013-9302-2 


\title{
Competition and $R \& D$ cooperation with universities and competitors
}

\author{
Thomas Bolli $\cdot$ Martin Woerter
}

Published online: 17 February 2013

(c) Springer Science+Business Media New York 2013

\begin{abstract}
This paper analyses the relationship between competitive environment and R\&D cooperation with universities and competitors. Our simple model suggests that cooperation creates benefits in terms of synergies but also induces costs due to spillovers. Since the value of these synergies and spillovers depends on the competitive pressure, cooperation propensity depends on the competitive environment. Differentiating between the dimensions of competition, we hypothesize that university cooperation corresponds to quality competition, while horizontal cooperation relates to price competition. Furthermore, we predict that a higher number of competitors reduces the incentives for horizontal cooperation as it diminishes the gains from "collusion". We test these hypotheses using Swiss firm-level panel data that allows us to control for simultaneity of cooperation decisions and endogeneity of competition. Our empirical analysis supports the relevance of distinguishing between competition dimensions and cooperation partners, respectively. We find that price competition has an influence on university cooperation in the form of an inverted U. Quality competition only has an influence on university cooperation and the relationship shows a U-form. Moreover, we see that the number of principal competitors reduces cooperation between competitors.
\end{abstract}

Keywords Innovation cooperation - University cooperation - Horizontal cooperation · Number of competitors · Price competition · Quality competition

JEL Classification $\mathrm{O} 3$

T. Bolli

Economics Department, Lancaster University, Lancaster, LA1 4YX, UK

e-mail: bolli@alumni.ethz.ch

M. Woerter $(\bowtie)$

ETH Zurich, KOF Swiss Economic Institute, 8092 Zurich, Switzerland

e-mail: woerter@kof.ethz.ch 


\section{Introduction}

Despite the fact that both innovation policy and competition policy aim to increase productivity by fostering technological change, they often seem to contradict each other (Shapiro 2002). Intellectual property rights (IPR) are an important example. They increase incentives for innovation but also create barriers to entry for potential competitors. Similarly, allowing research and development $(\mathrm{R} \& \mathrm{D})$ cooperation improves the innovation process, but might also result in anticompetitive behaviour and coordination among market players. Hence, innovation and competition policy are closely linked and influence each other. Recognizing this overlap, the US considers applications for research joint ventures more flexible in terms of antitrust concerns (see, e.g., Link et al. 2002, 2005).

Reflecting the disparity of these political questions, two largely independent strands of literature have developed. The first analyzes the relationship between competition and innovation (see, e.g., Schumpeter 1912, 1942; Arrow 1962; Aghion et al. 2005; Boone 2008a, b; Vives 2008). The second strand of literature investigates the determinants of R\&D cooperation and the choice of the R\&D partner (see, e.g., Cohen and Levinthal 1989, 1990; Veugelers 1997; Veugelers and Cassiman 1999; Cassiman and Veugelers 2002, 2005; Beneito 2006). Relatively little, however, is known about the relationship between the competitive environment and R\&D cooperation. Hence, this paper provides a bridge between these two related strands of literature.

The few papers that analyze the effect of market concentration on R\&D cooperation portray a mixed picture. While Hernán et al. (2003), Beneito (2003), Negassi (2004) and Röller et al. (2007) support an increasing relationship, Hayton et al. (2010) suggest a decreasing effect. To our knowledge, the only paper that differentiates between price and quality competition was written by Colombo et al. (2006), who do not find a significant relationship between a direct measure of price competition intensity and technological cooperation. Differentiating between cooperation partner types, Miotti and Sachwald (2003) find no evidence of market share influencing cooperation propensity.

Similarly, the scant amount of literature that exists on the question of whether a small number of market players results in collusion provides mixed evidence. While Oxley et al. (2009), Clougherty and Duso (2009) and Tong and Reuer (2010) find evidence for collusion, Woerter (2011) does not find a significant relationship between the number of principal competitors and cooperation. Eisenhardt and Schoonhoven (1996) however empirically show a positive relationship between the number of competitors and cooperation.

This paper extends the existing literature along two main lines. First, we develop a theoretical framework for the relationship between the competitive environment and R\&D cooperation. This framework refines previous work by differentiating between different cooperation partners and different dimensions of the competitive environment. Secondly, we test the resulting predictions empirically. Thereby we provide first empirical evidence for the differential impact of several competition dimensions on cooperation across partner types. In accordance with our theoretical framework, we further allow for nonlinearities of the effect.

Starting with the observation that cooperation takes place if the benefit of cooperation exceeds the cost of cooperation, our theoretical framework distinguishes three channels through which the R\&D cooperation affects profits. The main benefit, the synergy effect, increases research productivity, e.g. by pooling complementary resources. The second benefit, the collusion effect, occurs because R\&D cooperation facilitates collusion between rivals and thereby increases profits. However, the firm has to weigh these benefits against the costs arising due to knowledge spillovers, which we refer to as the spillover effect. 
As R\&D cooperation affects the benefits and costs of innovation, and competition changes the value of innovation, competition affects the incentives to cooperate. The form of the relationship between competition and cooperation depends on whether the synergy effect or spillover effect dominates. Assuming an inverted U-shaped relationship between competitive pressure and innovation value suggests an inverted U-shaped relationship between competitive pressure and cooperation propensity if the synergy effect dominates. Conversely, if the spillover effect prevails, we expect a U-shaped relationship.

Since the existing empirical evidence suggests that the nature of $R \& D$ projects in $R \& D$ cooperation differs substantially between cooperation partner types (Miotti and Sachwald 2003; Belderbos et al. 2004; Aschhof and Schmidt 2008), we complete our model by making according assumptions. Concretely we assume that university cooperation relates to product innovation while horizontal cooperation corresponds to process innovation. Though our framework extends to other types of cooperation partners as well, this paper focuses on cooperation with universities and horizontal partners as the existing empirical evidence provides little guidance in terms of the nature of $R \& D$ projects with other cooperation partner types, suggesting that the nature of $R \& D$ projects with other cooperation partner types is more heterogeneous.

In order to account for these differences between the cooperation goals, we differentiate two dimensions of competition intensity, namely price and quality competition. We further assume that the spillover effect is stronger for product innovation than for process innovation. Hence, we hypothesize that quality competitive pressure affects university cooperation in an inverted U-shape while price competitive pressure affects horizontal cooperation in a U-form.

The third channel, the ability of a firm to collude with its competitors as well as the benefits of collusion, depends on the market overview, suggesting a negative relationship between the number of principal competitors and horizontal cooperation.

Our empirical findings are based on comprehensive firm-level panel data of Swiss R\&D active manufacturing firms (Swiss Innovation Survey). In line with the broad body of existing literature, we confirm that R\&D cooperation creates synergies, as our proxies for incoming spillovers, absorptive capacity, and technological potential are positively related to both types of cooperation partners, though accounting for potential endogeneity weakens these results for horizontal cooperation.

Price competition intensity has an influence on university cooperation but not horizontal cooperation, though only after accounting for potential endogeneity. The relationship takes the form of an inverted U-shape, suggesting that the synergy effect dominates. The finding further indicates that university cooperation yields synergies in respect to process innovation. Furthermore we find a U-shaped relationship between quality competition and university cooperation, suggesting that the existence of knowledge spillover is more important than synergies. In line with our predictions, we do not find a relationship between quality competition and horizontal cooperation. We also find evidence that the value of collusion matters, since there is a decreasing relationship between the number of principal competitors and the probability of cooperation among competitors. In sum the results show that competition is significantly related to cooperation. Furthermore, the form of the relationship depends on the type of competition (price, quality, number of competitors) and on the type of partners.

The paper is organized as follows. Chapter two introduces our theoretical framework and derives corresponding hypotheses. Chapter three discusses the data and the empirical setup. Chapter four presents the results and chapter five concludes. 


\section{Theoretical notions and hypotheses}

Research cooperation takes place if it increases profits, i.e. if the benefits of cooperation exceed the costs of cooperation. In our simple framework, cooperation affects firm profits through three channels. The main benefit of cooperation is the improvement of innovation productivity, which we label synergy effect. Cooperation further increases the value of innovation through the collusion effect, i.e. by facilitating anticompetitive behaviour. However, cooperation also creates knowledge spillovers, thereby reducing the value of innovation. We refer to this channel as the spillover effect.

Hence, cooperation takes place if the benefits arising from the synergy and collusion effect outweigh the costs due to the spillover effect. The following paragraphs deepen our understanding of these relationships and derive hypotheses for the relationship between the competitive environment and R\&D cooperation.

We label the impact of cooperation on innovation productivity the synergy effect. Kamien et al. (1992) argue that the synergy effect arises because innovation cooperation eliminates wasteful duplication and hence increases research productivity. Similarly, Glaister and Buckley (1996) argue that economies of scale and the transfer of complementary resources create synergies. The magnitude of the synergy effect depends on how much knowledge spills over from the cooperation partner to the firm. Hence, the synergy effect increases in incoming spillovers (Cassiman and Veugelers 2002). The magnitude further depends on how well the firm can absorb and integrate the incoming knowledge flows. Therefore, the synergy effect increases with the absorptive capacity of the firm (Cohen and Levinthal 1989, 1990). Finally, the magnitude of the synergy effect depends on the extent of knowledge that exists outside of the firm as this constitutes the maximum of knowledge that can spill over from the cooperation partner to the firm. Hence, the synergy effect increases in technological opportunity.

Hypothesis 1: Incoming spillovers, absorptive capacity and technological potential increase the probability of $R \& D$ cooperation.

The synergy effect as defined so far does not create a relationship between the competitive environment and cooperation. However, assuming that the value of enhancing innovation depends on competition suggests a relationship between competition and cooperation as well, since the benefits and costs of cooperation increases as the innovation value rises. The existing literature suggests three potential relationships between competition and innovation value. First, Schumpeter (1912, 1942) argued that competition decreases the expected profits reaped from innovating and hence reduces the incentives to invest in R\&D. Secondly, Arrow (1962) suggests a positive relationship between competition and innovation due to the replacement effect, i.e. that firms in concentrated markets may refrain from introducing new innovative products since (great) parts of the revenues of older product would just be shifted to the new, innovative product. Technological lock-in effects further compound the opportunity cost of innovation and make it unlikely that a firm in a highly concentrated market switches to a new technology in order to substitute the old product (Geroski 1990). Thirdly, combining the arguments of Schumpeter and Arrow, Gilbert (2006) suggests that moderate levels of competition are most conducive to innovation, while very low or very high levels of competition reduce the incentives to innovate. Empirical tests confirm the inverted U-shaped relationship between innovation and competition (see, e.g., Levin et al. 1985; Aghion et al. 2005). Hence, we assume that competition and innovation value are inverted U-shape related. Based on these results, i.e. that the probability of cooperation increases as the value of the synergies it 
creates rises, and that the value of innovation and synergies follows an inverted U-shaped relationship with competition, we can see that the synergy effect suggests that competition increases the incentives for cooperation at low levels of competition but decreases the incentives for cooperation at high levels of competition.

However, the synergy effect is counterbalanced by the spillover effect, which arises because cooperation increases outgoing spillovers and thereby enhances competition. ${ }^{1}$ These effects can be indirect, e.g. in the case of universities, where the knowledge acquired by the university in the course of a cooperation is spread to the wider economy through technology transfer activities with other cooperation partners (see, e.g., Hall et al. 2001; Jirjahn and Kraft 2011). The spillover effect resembles the synergy effect in the sense that the relationship between competition and cooperation depends on the relationship between the value of innovation and competition. Assuming (again) an inverted U-shape relationship between the value of innovation and competition, we can see that the value of spillovers also increases with low levels of competition and decreases with high levels of competition. Since spillovers are lowering profits, it is clear that competition decreases the incentives for cooperation at low levels of competition but increases the incentives for cooperation at high levels of competition. Hence we can see a U-shaped relationship between cooperation and competition when referring to spillovers.

Since the synergy effect and the spillover effect suggest a converse relationship between cooperation and competition, the predicted form of the relationship depends upon whether the spillover effect or the synergy effect prevails. If the synergy effect dominates, we expect an inverse U-shaped relationship. If the spillover effect prevails, we see a U-shaped relationship between competition and cooperation.

In this paper, we focus on two types of cooperation partners, namely cooperation with universities and horizontal cooperation with competitors. The existing empirical evidence suggests that the nature of $R \& D$ cooperation projects differs between these cooperation partners. Concretely, it suggests that cooperation agreements with universities focus on basic research projects (Hall et al. 2001, 2003, Medda et al. 2005), leading to product innovation (Miotti and Sachwald 2003; Belderbos et al. 2004; Aschhof and Schmidt 2008). Beise and Stahl (1999) also confirm that academic research has a greater impact on product innovation than on process innovation. Horizontal cooperation on the other hand stimulates productivity but doesn't necessarily induce product innovation (Miotti and Sachwald 2003; Belderbos et al. 2004; Aschhof and Schmidt 2008). Similarly, Jirjahn and Kraft (2011) show that horizontal cooperation increases incremental innovations but has no influence on drastic innovations, while the opposite holds for university cooperation. These empirical findings suggest that university cooperation projects aim at product innovation, while horizontal cooperation projects aim at process innovation.

Furthermore, we learn from the findings of Ornaghi (2006) that the spillover effect is stronger in the case of product innovation than in the case of process innovation. The main explanation for this empirically sound result is that product innovation, once commercialised, can be relatively easily copied, e.g., through reverse engineering, while copying new processes is much more difficult. The later would require a kind of industrial espionage in order to copy the new, innovative production process. Given the fact that cooperation with universities mainly focuses on product innovation and that the spillovers are stronger for product innovations we would assume that the spillover effect dominates the

\footnotetext{
${ }^{1}$ Bloom et al. 2010 distinguish between a technology spillover effect and a measure of product market closeness. In our setting technology spillovers are referred to as synergy effect and product market closeness is related to our measure of spillovers.
} 
synergy effect for university cooperation and that the synergy effect dominates the spillover effect in the case of horizontal cooperation. Moreover, we know from the empirical literature on the dynamics of product and process innovation (see Utterback and Abernathy 1975; Adner and Levinthal 2001) that process innovation aiming at lowering production costs is positively related to price competition, while product innovation aiming at exploring new markets or enhancing existing markets is positively related to quality competition (e.g., product differentiation).

Bringing together the above mentioned facts, namely that university cooperation mainly aims at product innovations, in which spillovers and quality competition dominate, and that horizontal cooperation has a stronger focus on process innovations, in which synergies and price competition dominate, we state the following hypotheses:

(2a) Price competition doesn't affect university cooperation

(2b) Price competition affects horizontal cooperation in the form of an inverted $U$ since the synergy effect prevails

(3a) Quality competition affects university cooperation in the form of a U-form since the spillover effect prevails

(3b) Quality competition doesn't affect horizontal cooperation

Hypotheses 2 and 3 have never been tested empirically. The scant empirical literature there is focuses on market concentration as a measure of competition and hence fails to distinguish between the type of cooperation partner and the potential non-linearity of the effect. Therefore it provides little guidance in respect to our hypotheses 2 and 3. Concretely, Hernán et al. (2003), Röller et al. (2007), Negassi (2004) and Beneito (2003) support the hypothesis that cooperation increases as markets become more concentrated, while Hayton et al. (2010) find a negative relationship between market concentration and cooperation. To our knowledge, the only paper that differentiates between price and quality competition was written by Colombo et al. (2006), who do not find a significant relationship between a direct measure of price competition intensity and technological cooperation. The only paper that differentiates between different types of cooperation partners finds no impact of market concentration on university, horizontal and vertical cooperation propensity (Miotti and Sachwald 2003).

The last channel through which the competitive environment affects cooperation, the collusion effect, increases price-cost margin and hence profit. It occurs because horizontal cooperation reduces the number of effective competitors and hence competitive pressure. The collusion effect is strongest for a duopoly and decreases as competition intensifies, as shown empirically by Oxley et al. (2009) and Tong and Reuer (2010). Hence, the value of such a colluding $\mathrm{R} \& \mathrm{D}$ cooperation decreases with the number of principal competitors, suggesting the following hypothesis:

Hypothesis 4: (a) The number of principal competitors has no impact on university cooperation

(b) The number of principal competitors reduces horizontal cooperation

However, while Clougherty and Duso (2009) find evidence of the collusion effect, they show no differences of this effect across market concentration. Furthermore, Woerter (2011) does not find a significant relationship between the number of principal competitors and cooperation. Eisenhardt and Schoonhoven (1996) however argue that the value of cost and risk sharing increases when there is competition and empirically demonstrate a positive relationship between the number of competitors and cooperation. Hence, the existing empirical evidence provides mixed expectations for hypothesis $4 \mathrm{~b}$. 


\section{Data and methodology}

\subsection{Data}

We use a panel of Swiss firms observed across five periods (1996, 1999, 2002, 2005, and 2008). The Swiss Economic Institute (KOF) at ETH Zurich collected the data through five postal surveys, using a questionnaire similar to the "Community Innovation Survey" (available from www.kof.ethz.ch ${ }^{2}$ ). ${ }^{3}$ The data includes information on firm characteristics, innovation activities and R\&D activities, among other things. The surveys are based on a stratified random sample of firms that have at least five employees and cover all relevant industries in the manufacturing, construction, and service sectors. The sample employed includes only R\&D active manufacturing firms, thereby ensuring sample homogeneity and hence internal validity. Dropping observations with missing values yields a highly unbalanced firm-panel with 3,057 observations.

\subsection{Empirical setting}

The empirical estimation consists of four equations with binary dependent variables, which indicate whether a firm has conducted innovation cooperation with a particular partner type within the previous three years $\left(\mathrm{COOP}_{\mathrm{u}}, \mathrm{COOP}_{\mathrm{h}}, \mathrm{COOP}_{\mathrm{v}}, \mathrm{COOP}_{\mathrm{g}}\right)$. Subscripts $\mathrm{k}=\{\mathrm{u}, \mathrm{h}$, $\mathrm{v}, \mathrm{g}\}$ denote coefficients of the estimation with university, horizontal, vertical and company group internal (or concern internal) cooperation as dependent variable, respectively:

$$
\begin{aligned}
& \operatorname{prob}\left[\operatorname{COOP}_{\mathrm{k}, \mathrm{i}, \mathrm{t}}=1 \mid \mathrm{COOP}_{-\mathrm{k}, \mathrm{i}, \mathrm{t}}\right]=\operatorname{prob}\left[\beta_{\mathrm{k}, 0}+\beta_{\mathrm{k}, \mathrm{t}}+\beta_{\mathrm{k}, \mathrm{j}}+\beta_{\mathrm{k}, 1} \operatorname{SPILLINC}_{\mathrm{i}, \mathrm{t}-1} .\right. \\
& +\beta_{\mathrm{k}, 2} \operatorname{ABSCAP}_{\mathrm{i}, \mathrm{t}-1}+\beta_{\mathrm{k}, 3} \operatorname{TECHPOT~}_{\mathrm{i}, \mathrm{t}}+\beta_{\mathrm{k}, 4} \operatorname{APPROP}_{\mathrm{i}, \mathrm{t}-1}+\sum_{\mathrm{h}} \beta_{\mathrm{k}, 5}^{\mathrm{h}} \text { QUALCOMP }_{\mathrm{i}, \mathrm{t}-1}^{\mathrm{h}} \\
& \left.+\sum_{\mathrm{h}} \beta_{\mathrm{k}, 6}^{\mathrm{h}} \text { PRICECOMP }_{\mathrm{i}, \mathrm{t}-1}^{\mathrm{h}}+\beta_{\mathrm{k}, 7} \text { COMPETITORS }_{\mathrm{i}, \mathrm{t}-1}+\beta_{\mathrm{k}, 8} \operatorname{Control}_{\mathrm{i}, \mathrm{t}-1}+\varepsilon_{\mathrm{k}, \mathrm{i}, \mathrm{t}} \geq 0\right]
\end{aligned}
$$

where $\mathrm{i}$ refers to firm, $\mathrm{j}$ to industry (two-digit level) and to time. $\mathrm{h}=\{1,2\}$ describes the quadratic polynomial of variables measuring quality and price competition intensity. In order to account for interdependence between cooperation choices, we estimate the equation system described by Eq. 5 using a multivariate probit model, i.e. a SUR model with binary dependent variables. Assuming a multivariate normal distribution of the robust

\footnotetext{
${ }^{2}$ Questionnaires are available in German, Italian, and French.

3 The KOF (Swiss Economic Institute; www.kof.ethz.ch) at ETH Zurich is specialized in collecting firmlevel survey data. Data collection takes place following very strict guidelines. All waves of the surveys are conducted based on the same firm panel (stratified sample (2-digit sectors, 3 firm-size classes, with full coverage of the upper class of firms) of around 6,600 firms. The number of observations (response rates) is 1,748 firms (32.5\%), 2,172 firms (33.8\%), 2,583 firms (39.6\%), 2,555 firms (38.7\%), and 2,141 firms $(36.1 \%)$ for the years 1996, 1999, 2002, 2005 and 2008, respectively. The firm directory is regularly updated. There are strict rules for handling firms that don't answer. Every survey is accompanied by an intensive recall action conducted by trained staff. The recall action should guarantee an equilibrated response rate across the statistical cells (sector/firm size). Every returned questionnaire is manually checked by a researcher for consistency. The researcher calls the firm if inconsistent answers are detected. The regular survey is followed by a non-response survey in order to detect a possible non-response bias for key questions. Based on the mail that is returned unanswered we can detect which firms have exited the market. Exiting firms are substituted by (statistically) similar firms.
} 
error terms clustered at firm level, $\varepsilon_{\mathrm{u}}, \varepsilon_{\mathrm{h}}, \varepsilon_{\mathrm{v}}$ and $\varepsilon_{\mathrm{g}}$, we estimate the system by simulated maximum likelihood with 400 draws (see, e.g., Greene 2003, p. 710).

The vector of independent variables follows our theoretical framework as well as the empirical model specification of Cassiman and Veugelers (2002). Table 1 provides details about the construction of variables. Tables 3 and 4 in the appendix display summary statistics and pair-wise correlations of the employed variables.

We measure the relevance of spillovers (SPILLINC) as the average importance of several information sources, including universities, horizontal, vertical and company group internal (or concern internal) information sources. The share of R\&D employees captures absorptive capacity (ABSCAP). The data further allows us to control for technological potential outside of the firm (TECHPOT) ${ }^{4}$ The inverse of the innovation obstacle "easiness to copy" approximates appropriability (APPROP), since we assume that appropriability is low if competitors can easily copy innovation results and vice versa.

Following Belderbos et al. (2004), we include the relevance of the innovation obstacle "high costs" in the control vector. This cost variable (OCOST) refers to the costs of innovation activities. Hence, OCOST captures the Schumpeterian idea (Schumpeter 1942) that innovation activities require substantial financial resources. Finally, we control for firm size measured by the number of full-time employees (SIZE) and its square (SIZE^2), whether a firm is foreignowned (FOREIGN), whether the firm is an exporter (EXPORTER) as well as time and industry dummies. Including these variables has shown to be empirically relevant for small open economies, like Switzerland (see, e.g., Arvanitis et al. 2008; Arvanitis and Stucki 2012) Furthermore we control for industry fixed effects (two-digit level) and time fixed effects.

Due to the multifaceted nature of the competition concept, the existing literature remains divided on the question of how to measure competition (see, e.g., Boone 2008a, b; Vives 2008). In this paper, we use subjective evaluations of the firms themselves to measure competition. Using these firm-specific evaluations has the advantage that it allows us to differentiate between different dimensions of competition (price competition, quality competition, number of principal competitors). Furthermore, our competition measures are not limited to the domestic market but take into account the worldwide markets, a feature which is of great importance for a small, technologically advanced country like Switzerland. Finally, these competition measures take into account the distinct characteristics of the firms' market, which is particularly relevant in the case of Swiss firms as they often produce for a small market niche that can hardly be proxied by competition measures referring to broad industry classifications. However, the subjectivity of the response makes our results vulnerable to potential biases in the evaluation of competition. In order to address this criticism, we also calculate our measures of competition by taking the average of the competition measure of firms in the two-digit industry. ${ }^{5}$

Concretely, we include linear and quadratic terms of two types of competition dimensions, namely the intensity of price and quality competition (PRICECOMP, PRICECOMP_SQU, QUALCOMP, QUALCOMP_SQU) measured on a five point Likert scale ( 1 very weak ... 5 very strong). Furthermore, we can identify the number of principal competitors according to five categories, namely $0-5,6-10,11-15,16-50$ and more than 50 principal competitors (NCOMP). ${ }^{6}$

\footnotetext{
4 Technological potential is defined as the globally available private and public knowledge that might be useful for the creation of new products and services based on the applied technology. Firms were asked in a questionnaire to evaluate the technological potential on a five point Likert scale (1 very low ... 5 very high).

5 We are grateful to an anonymous referee for this point.

6 The five categories are given in the questionnaire.
} 
Table 1 Variable definitions

\begin{tabular}{ll}
\hline Name $\quad$ Definition & Expected effect \\
\cline { 2 - 3 } & COOP COOP \\
& UNI HOR
\end{tabular}

Dependent

variables

COOP UNI Binary variable whether a firm has worked in R\&D cooperation with universities or other research institutions in the last 3 years (yes/no)

COOP HOR Binary variable whether a firm has worked in R\&D cooperation with competitors in the last 3 years (yes/no)

COOP VERT Binary variable whether a firm has worked in R\&D cooperation with suppliers or customers in the last 3 years (yes/no)

COOP Binary variable whether a firm has worked in R\&D cooperation with

GROUP other firms in the same company group (in the same concern) in the last 3 years (yes/no)

Explanatory

variables

PRICECOMP Category of price competition intensity on a five point Likert scale (1 very weak ... 5 very strong)

QUALCOMP Category of non-price, or quality competition intensity on a five point Likert scale (1 very weak ... 5 very strong)

NCOMP Category of number of principal competitors between 1 and $5(0-5$, 6-10, 11-15, 16-50, $50+$ competitors)

SPILLINC Incoming spillovers, calculated as the average relevance of universities, other research institutions, competitors, suppliers, customers and firm groups as a source of information for the R\&D activity on a five point Likert scale (1 none ... 5 very important)

ABSCAP Absorptive capacity, measured by the share of R\&D employees

TECHPOT Technological potential outside the firm on a five point Likert scale (1 very low ... 5 very high)

APPROP Appropriability, measured by six minus the relevance of the innovation obstacle "easiness to copy" on a five point Likert scale ( 1 none ... 5 crucial)

OCOST Binary variable that is 1 if the relevance of the innovation obstacle "high costs" scores 4 or 5 on a five point Likert scale ( 1 none ... 5 crucial), and 0 otherwise

SIZE Number of full time employees

EXPORTER Binary variable that takes the value 1 if the firm exports abroad, and 0 otherwise

FOREIGN Binary variable that is 1 if the majority of the firm is foreign-owned, and 0 otherwise

$\mathrm{U}$ and $\cap$ mean a U-shaped and inverse $\mathrm{U}$-shaped relationship, respectively

$+{ }^{+}$and ${ }^{-}$denote significant positive and significant negative relationship, respectively; 0 means no relationship

We address potential problems of endogeneity and measurement error (see, e.g., Gilbert 2006) by instrumenting the number of principal competitors (NCOMP), price competition intensity (PRICECOMP), quality competition intensity (QUALCOMP) and technological potential (TECHPOT) based on the lagged industry averages. ${ }^{7}$

\footnotetext{
7 We manually implement the IV estimator, i.e. estimate the first stage using OLS and include the predicted values for both linear and quadratic terms in the second stage multivariate probit estimations.
} 
Table 1 summarizes our hypotheses. Incoming spillovers, absorptive capacity, technological potential and appropriability should be positively related to both types of cooperation. Quality competition relates to university cooperation but has no impact on horizontal cooperation. Conversely, price competition is expected to affect horizontal cooperation only. The number of principal competitors should be negatively related to horizontal cooperation.

\section{Results}

Table 2 displays multivariate probit models for university, horizontal, vertical and company group internal (or concern internal) cooperation. Columns 1 to 4 use contemporary values of regressors. Columns 5 to 8 use lagged regressors by 3 years (the surveys are conducted every 3 years) and use industry averages of competition measures and technological potential to account for potential endogeneity, reverse causality and measurement error. Columns 9 to 12 also use lagged regressors, instrument competition measures and technological potential by their corresponding industry averages formally. Table 6 in the appendix demonstrates that instruments display a significant predictive power in the first stage.

Table 2 shows that SPILLINC, ABSCAP, and TECHPOT are positively related to university cooperation, suggesting the presence of synergies and hence supporting hypothesis 1 . The evidence remains more ambiguous regarding horizontal cooperation. Concretely, while the contemporary estimates suggest a positive effect of technological potential and incoming spillovers, accounting for potential reverse causality renders these indicators of synergies insignificant. Furthermore, we see a positive effect of appropriability (APPROP) on university cooperation in the contemporary estimations that disappears when using lagged values of the variable. Similarly, we find no evidence for an impact of appropriability on the propensity to cooperate with horizontal partners.

Hypothesis 2 a predicts that price competition (PRICECOMP) and university cooperation are unrelated, while hypothesis $2 \mathrm{~b}$ predicts a significant relationship between price competition and horizontal cooperation. Rather surprisingly, simple correlations only support hypothesis $2 \mathrm{a}$ as price competition intensity affects neither university nor horizontal cooperation significantly in the base estimation (columns 1 and 2; Table 2). However, instrumenting price competition yields an inverse U-shaped relationship between price competition and university cooperation, suggesting that the synergy effect dominates the spillover effect in the relationship. This finding further suggests that university cooperation leads to synergies in respect to process innovation.

Hypothesis 3a suggests that quality competition (QUALCOMP) and university cooperation have a significant U-shaped relationship. Hypothesis $3 \mathrm{~b}$ claims that quality competition has no impact on horizontal cooperation. Table 2 supports these hypotheses, as we find a U-shaped relationship between quality competition and university cooperation and no correlation between quality competition and horizontal cooperation. Hence, we see that the spillover effect outpaces the synergy effect in the case of quality competition.

Quality competition shows a U-shaped relationship with university cooperation, while the functional form follows an inverted U-shape in the case of price competition. This difference between the two competition types suggests that appropriability and hence the spillover effect matters more for product innovation than for process innovation, which is 


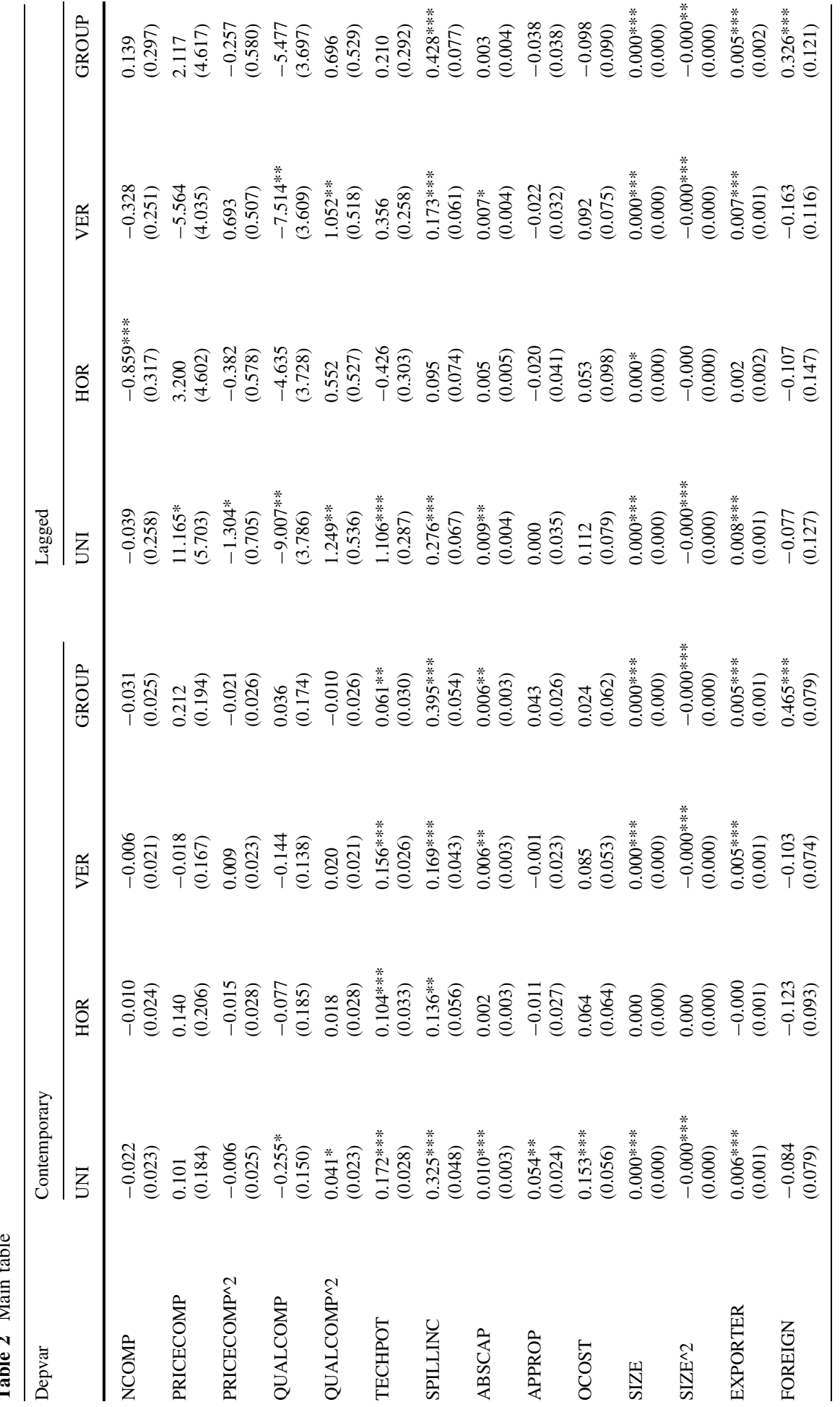




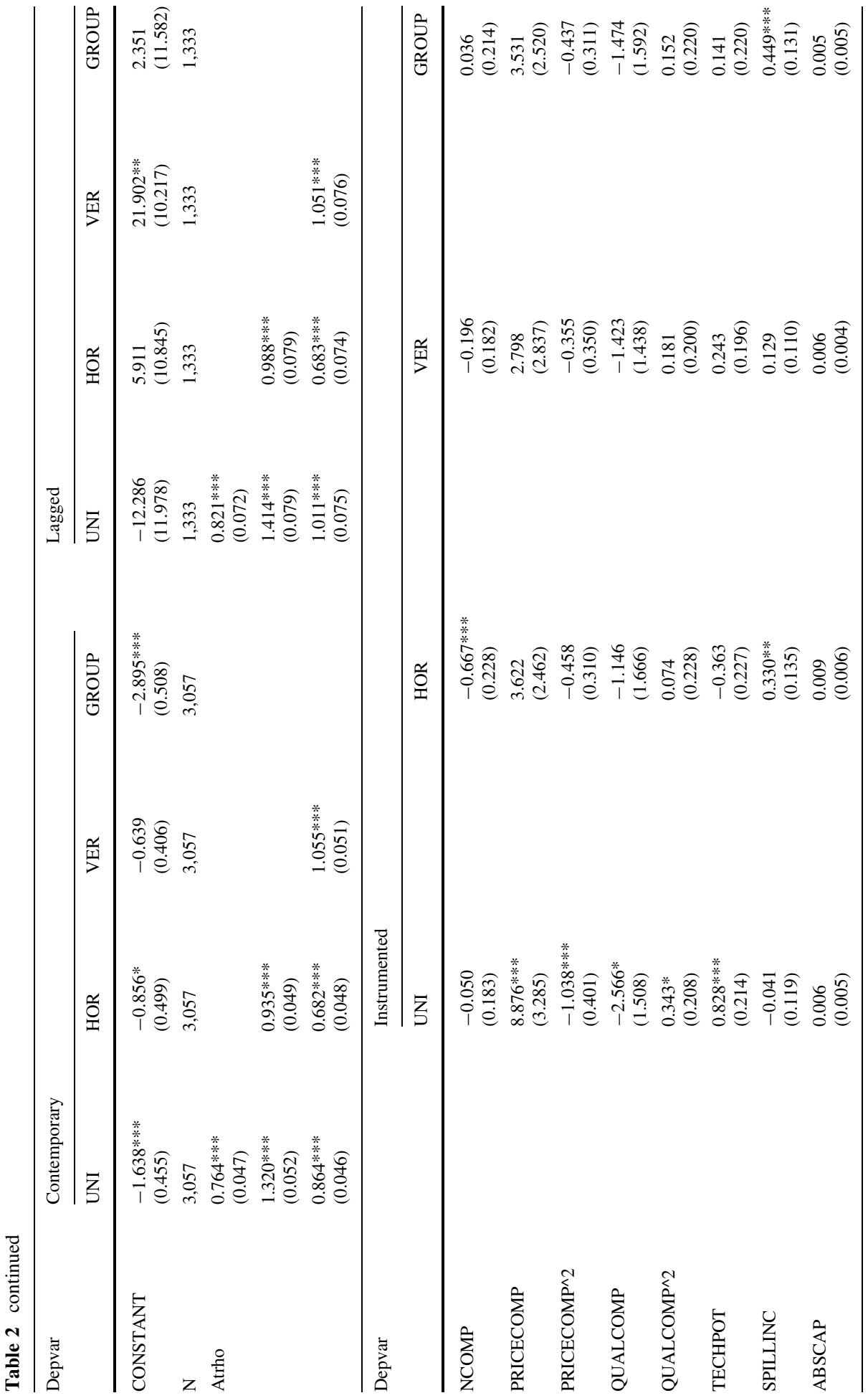




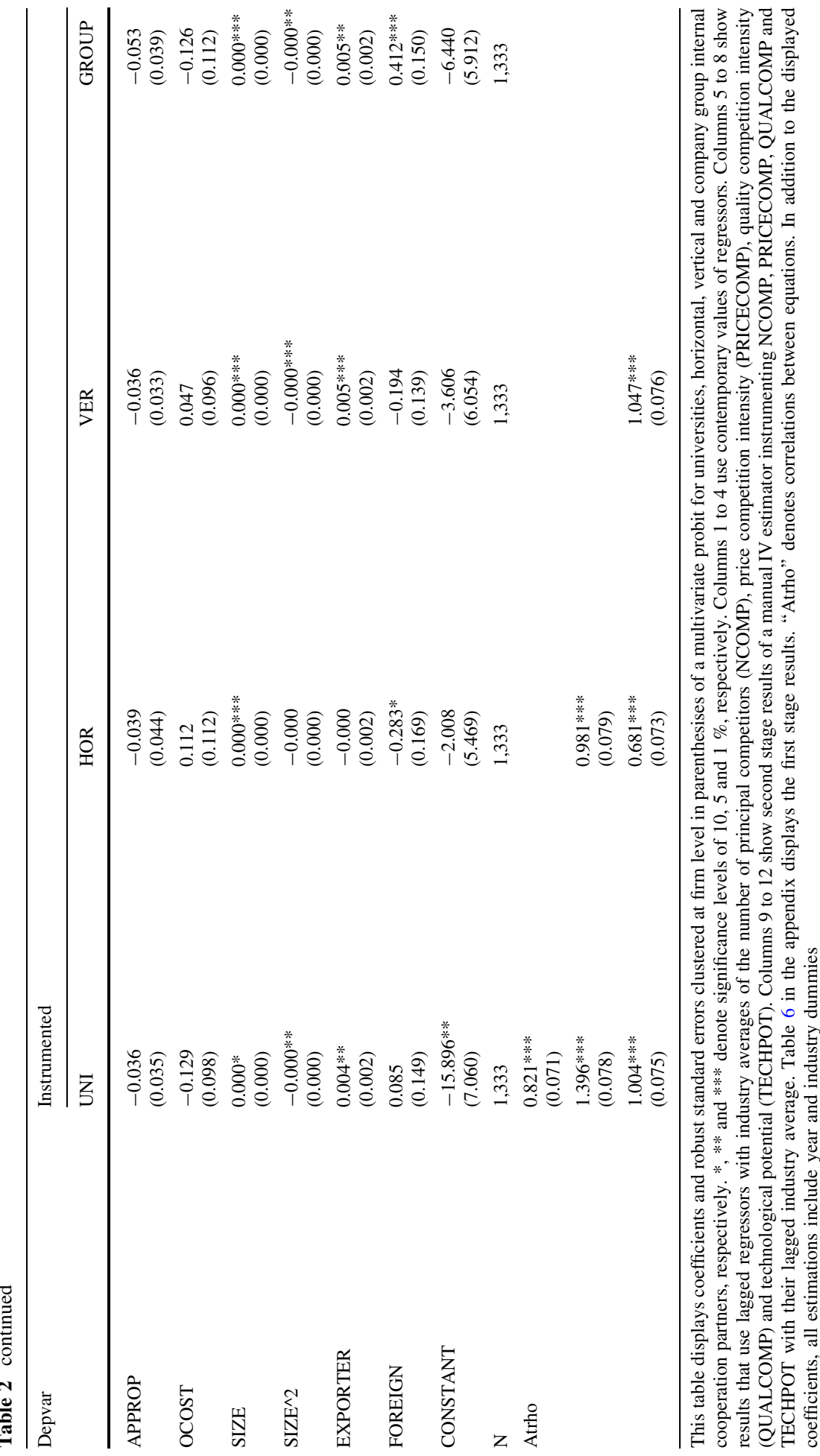


consistent with the differences in the significance of appropriability in the non-instrumented university and horizontal cooperation equations.

Confirming both hypotheses $4 \mathrm{a}$ and $4 \mathrm{~b}$, Table 2 further reveals that the number of competitors (NCOMP) decreases horizontal cooperation but has no effect on university cooperation.

Furthermore, our results show that financial constraints, measured by OCOST, are related to the probability of university cooperation, though the effect disappears in the more sophisticated estimations. OCOST is not significantly related to horizontal cooperation. This finding implies that the cost-sharing motive might apply to university cooperation, while alternative reasons motivate horizontal cooperation.

We further control for firm size (SIZE, SIZE^ ${ }^{\wedge}$ ), exporter status (EXPORTER), foreign ownership (FOREIGN), time fixed effects and industry fixed effects. Firm size relation to both types of cooperation follows a U-shape. Exporter status relates positively to university cooperation but not to horizontal cooperation. Foreign ownership is unrelated to cooperation with both partner types.

Table 2 further allows us to assess the nature of vertical and company group internal cooperation. Vertical cooperation behaves somewhat similar to university cooperation in respect to competition. Concretely, it remains unaffected by the number of competitors, but displays some indication of a U-shaped pattern for quality competition. It however remains unaffected by price competition. Furthermore, the relevance of spillovers and absorptive capacity increases vertical cooperation. Appropriability, however, does not affect cooperation with vertical partners. Furthermore, financial constraints (OCOST) do not matter, suggesting that the ability of universities to overcome financial constraints does not extend to vertical cooperation partners.

Company group internal cooperation is unaffected by our competition measures. Furthermore, we do not find evidence for a spillover effect as appropriability remains insignificant. However, the significance of the relevance of spillovers, absorptive capacity and technological potential suggests the presence of a synergy effect.

\section{Conclusions}

The investigation at hand looks at the meaning of competition for the choice of cooperation partners distinguishing between two types of cooperation partner, i.e. universities and horizontal partners. Thereby we are contributing to two strands of literature: First, we extend the literature addressing the relationship between the competitive environment and decisions related to R\&D and innovation (see, e.g., Schumpeter 1912, 1942, Arrow 1962, Aghion et al. 2005, Boone 2008a, b and Vives 2008). We do so by clarifying and analyzing the particular forces that relate the competitive environment to $R \& D$ cooperation. Secondly, we extend the, investigations that look at the determinants of innovation cooperation and the choice of partners by showing that different dimensions of the competitive environment differ in their effect on the propensity to cooperate with universities and horizontal firms (e.g. Veugelers 1997; Cassiman and Veugelers 2002, 2005; Hernán et al. 2003; Beneito 2003; Negassi 2004).

Our simple theoretical framework distinguishes three channels through which competition affects innovation cooperation. First, the synergy effect arises because the value of innovation synergies changes as competition intensifies. Secondly, the changing value of innovation spillovers (spillover effect) affects the costs of cooperation. Thirdly, the value of collusion (collusion effect) increases in market overview. 
Using Swiss firm level data, we confirm our assumptions that university cooperation but not horizontal cooperation corresponds to quality competition and hence product innovation. In addition, university cooperation responds to price competition after instrumentalisation, suggesting that universities provide synergies in respect to process innovation. Furthermore, our results support the hypothesis of a collusion effect as horizontal cooperation decreases with the number of principal competitors.

An interpretation of our results in terms of competition emphasises two points.

First, competition plays a different role for horizontal and university cooperation, respectively. We do not see any effect of appropriability or quality competition for horizontal cooperation, which indicates that other factors drive firms to collaborate with competitors. In fact, it is the number of principal competitors that provides incentives for horizontal cooperation. Thus, market overview seems to be more important than synergies in innovation activities. In contrast, the number of principal competitors is not important for cooperation with universities. Here, both price and quality competition are important driving forces. Firms try to realize synergies in innovation activities and they take care of outgoing spillovers that might increase product market competition.

Secondly, our results suggest that innovation policy and competition policy are related (see Teece 1992). R\&D cooperation is intended to improve the innovation performance of firms. We found that quality competition is U-shape related with university collaborations and unrelated with horizontal cooperation. Based on these results one can suggest that, if competition policy emphasises the number of principal competitors as an important criteria, competition policy discourages $R \& D$ cooperation with competitors. Regarding R\&D cooperation with universities and price competition, our results suggest that competition authorities should aim to create a medium level of competitive pressure in order to optimize $R \& D$ cooperation and innovation. The inverse holds true for quality competition. R\&D cooperation is high for low and high levels of quality competition while medium levels of quality competition discourage cooperation with universities. Since this suggests that spillovers are particularly relevant for product innovations, intellectual property rights (IPR) might serve as a bridge between competition policy and innovation policy. Concretely, a medium level of quality competition can be avoided by ensuring a highly competitive market that is also characterized by temporary monopolies granted by IPR. Hence, competition policy aligns well with innovation policy if it aims at medium levels of price competition and either low or high levels of product competition.

While our data allows distinguishing between cooperation partner type and competition dimension, we have no direct information regarding the concrete nature of the cooperation projects, forcing us to make indirect inference. Looking more deeply into this 'black box' of cooperation projects is an important research direction that this paper points to. Moreover it would be interesting to see if the results for Switzerland also hold true for countries with different industry structures or larger domestic markets. It is likely that the size of the home market influences the significance of competition for firm/university cooperation; a more intense quality competition in the domestic market might increase the sensitivity of firms for potential spillovers. Finally, while the availability of panel data allows us to tackle potential endogeneity, the empirical strategy is not based on a natural experiment and therefore some doubts in respect to 
the causal interpretation of our results remain. Future research should therefore confirm this claim.

Acknowledgments The authors would like to thank the participants of the Annual Conference of the Technology Transfer Society 2010 and the Empirical IO Workshop KOF-ETH/UNISG 2010 for their comments. Thomas Bolli thanks the Swiss National Science Foundation for its financial support.

\section{Appendix}

See Tables 3, 4, 5, 6 .

Table 3 Summary statistics

\begin{tabular}{llrrll}
\hline Variable & Obs & Mean & SD & Min & Max \\
\hline COOP UNI & 3,057 & 0.27 & 0.45 & 0 & 1 \\
COOP HOR & 3,057 & 0.13 & 0.33 & 0 & 1 \\
COOP VERT & 3,057 & 0.35 & 0.48 & 0 & 1 \\
COOP GROUP & 3,057 & 0.17 & 0.38 & 0 & 1 \\
NCOMP & 3,057 & 2.37 & 1.30 & 1 & 5 \\
PRICECOMP & 3,057 & 4.02 & 0.96 & 1 & 5 \\
QUALCOMP & 3,057 & 3.35 & 0.92 & 1 & 5 \\
SPILLINC & 3,057 & 2.77 & 0.64 & 1 & 4.81 \\
ABSCAP & 3,057 & 8.95 & 10.69 & 0 & 100 \\
TECHPOT & 3,057 & 3.13 & 1.05 & 1 & 5 \\
APPROP & 3,057 & 3.44 & 1.19 & 1 & 5 \\
OCOST & 3,057 & 0.43 & 0.50 & 0 & 1 \\
SIZE* & 3,057 & 271.96 & 943.06 & 1 & 21,000 \\
EXPORTER & 3,057 & 45.46 & 37.05 & 0 & 100 \\
FOREIGN & 3,057 & 0.18 & 0.38 & 0 & 1 \\
FIRM AGE & 2,994 & 65.48 & 43.45 & 2 & 648 \\
\hline
\end{tabular}

* The sample is based on firms with more than 5 employees. However, at the time the survey was conducted the number of employees of some of the firms dropped below 5

Table 4 Pairwise correlation coefficients

\begin{tabular}{lrlrrrrl}
\hline & $\begin{array}{l}\text { COOP } \\
\text { UNI }\end{array}$ & $\begin{array}{l}\text { COOP } \\
\text { HOR }\end{array}$ & $\begin{array}{l}\text { COOP } \\
\text { VERT }\end{array}$ & $\begin{array}{l}\text { COOP } \\
\text { GROUP }\end{array}$ & NCOMP & PRICECOMP & QUALCOMP \\
\hline COOP UNI & 1.00 & & & & & & \\
COOP HOR & 0.34 & 1.00 & & & & & \\
COOP VERT & 0.68 & 0.42 & 1.00 & & & & \\
COOP GROUP & 0.47 & 0.28 & 0.51 & 1.00 & & & \\
NCOMP & -0.05 & 0.01 & -0.03 & -0.06 & 1.00 & & \\
PRICECOMP & 0.06 & 0.04 & 0.06 & 0.05 & 0.14 & 1.00 & \\
QUALCOMP & 0.07 & 0.05 & 0.03 & 0.04 & 0.06 & -0.01 & 1 \\
SPILLINC & 0.22 & 0.09 & 0.15 & 0.23 & -0.01 & 0.11 & 0.1519 \\
ABSCAP & 0.16 & 0.03 & 0.11 & 0.09 & -0.09 & -0.08 & 0.0607 \\
\hline
\end{tabular}


Table 4 continued

\begin{tabular}{|c|c|c|c|c|c|c|c|c|}
\hline & $\begin{array}{l}\text { COOP } \\
\text { UNI }\end{array}$ & $\begin{array}{l}\text { COOP } \\
\text { HOR }\end{array}$ & $\begin{array}{l}\text { COOP } \\
\text { VERT }\end{array}$ & $\begin{array}{l}\text { COOP } \\
\text { GROUP }\end{array}$ & NCOMP & \multicolumn{2}{|c|}{ PRICECOMP } & QUALCOMP \\
\hline TECHPOT & 0.24 & 0.10 & 0.20 & 0.15 & -0.02 & 0.0 & & 0.1224 \\
\hline APPROP & 0.04 & -0.02 & -0.01 & 0.03 & -0.07 & -0.08 & & -0.0229 \\
\hline OCOST & 0.10 & 0.04 & 0.08 & 0.03 & 0.01 & 0.1 & & 0.0313 \\
\hline SIZE & 0.17 & 0.15 & 0.13 & 0.17 & -0.01 & 0.0 & & 0.0764 \\
\hline EXPORTER & 0.24 & 0.01 & 0.20 & 0.20 & -0.21 & -0.0 & & 0.084 \\
\hline \multirow[t]{2}{*}{ FOREIGN } & 0.04 & -0.03 & 0.02 & 0.18 & -0.13 & -0.0 & & 0.0661 \\
\hline & SPILLINC & ABSCAP & $\mathrm{TE}$ & HPOT & APPROP & OCOST & SIZE & EXPORTER \\
\hline SPILLINC & 1.00 & & & & & & & \\
\hline ABSCAP & -0.01 & 1.00 & & & & & & \\
\hline TECHPOT & 0.31 & 0.15 & 1.0 & & & & & \\
\hline APPROP & -0.15 & 0.10 & 0.0 & & 1.00 & & & \\
\hline OCOST & 0.12 & 0.04 & 0.1 & & -0.21 & 1.00 & & \\
\hline SIZE & 0.1287 & 0.0628 & 0.1 & & 0.0167 & 0.022 & 1 & \\
\hline EXPORTER & 0.125 & 0.248 & 0.2 & & 0.084 & -0.0145 & 0.1042 & 1 \\
\hline FOREIGN & 0.1449 & 0.0696 & 0.0 & & 0.0494 & -0.0347 & -0.0014 & 0.2164 \\
\hline
\end{tabular}

Table 5 Sample distribution across industries and size classes

\begin{tabular}{lrrr}
\hline Industry/employees & $0-49$ & $50-249$ & $250+$ \\
\hline Food (1) & 63 & 104 & 76 \\
Textile (2) & 35 & 48 & 13 \\
Wood (4) & 44 & 36 & 5 \\
Paper (5) & 18 & 22 & 29 \\
Printing (6) & 31 & 52 & 15 \\
Chemicals (7) & 104 & 100 & 55 \\
Plastics/rubber (8) & 44 & 79 & 22 \\
Non-metallic minerals (9) & 35 & 41 & 20 \\
Basic metals (10) & 6 & 28 & 20 \\
Fabricated metals (11) & 126 & 177 & 47 \\
Machinery (12) & 206 & 301 & 149 \\
Electrical equipment (13) & 54 & 68 & 66 \\
Eletronic/optical products (14) & 161 & 184 & 84 \\
Watches (15) & 27 & 48 & 17 \\
Vehicles (16) & 12 & 24 & 16 \\
Other manufacturing (17) & 40 & 61 & 14 \\
Energy (18) & 2 & 10 & 18 \\
\hline
\end{tabular}


Table 6 Instrumental equations

\begin{tabular}{|c|c|c|c|c|}
\hline $\mathrm{N}=1,333$ & NCOMP & PRICECOMP & QUALCOMP & TECHPOT \\
\hline NCOMP_wk & $\begin{array}{l}1.514 * * * \\
(0.216)\end{array}$ & $\begin{array}{l}0.049 \\
(0.158)\end{array}$ & $\begin{array}{l}-0.272 * \\
(0.162)\end{array}$ & $\begin{array}{l}-0.043 \\
(0.161)\end{array}$ \\
\hline PRICECOMP_wk & $\begin{array}{l}-0.130 \\
(0.280)\end{array}$ & $\begin{array}{l}1.380 * * * \\
(0.210)\end{array}$ & $\begin{array}{l}0.002 \\
(0.205)\end{array}$ & $\begin{array}{l}-0.186 \\
(0.202)\end{array}$ \\
\hline QUALCOMP_wk & $\begin{array}{l}-0.159 \\
(0.268)\end{array}$ & $\begin{array}{l}0.072 \\
(0.175)\end{array}$ & $\begin{array}{l}1.504 * * * \\
(0.195)\end{array}$ & $\begin{array}{l}-0.139 \\
(0.198)\end{array}$ \\
\hline TECHPOT_wk & $\begin{array}{l}-0.061 \\
(0.239)\end{array}$ & $\begin{array}{l}-0.088 \\
(0.156)\end{array}$ & $\begin{array}{l}-0.019 \\
(0.149)\end{array}$ & $\begin{array}{l}1.346^{* * * *} \\
(0.175)\end{array}$ \\
\hline SPILLINC & $\begin{array}{l}-0.018 \\
(0.063)\end{array}$ & $\begin{array}{l}0.107 * * \\
(0.043)\end{array}$ & $\begin{array}{l}0.148 * * * \\
(0.045)\end{array}$ & $\begin{array}{l}0.378 * * * \\
(0.045)\end{array}$ \\
\hline ABSCAP & $\begin{array}{l}-0.003 \\
(0.005)\end{array}$ & $\begin{array}{l}-0.003 \\
(0.003)\end{array}$ & $\begin{array}{l}0.006^{*} \\
(0.003)\end{array}$ & $\begin{array}{l}0.007 * * \\
(0.003)\end{array}$ \\
\hline APPROP & $\begin{array}{l}-0.019 \\
(0.033)\end{array}$ & $\begin{array}{l}0.001 \\
(0.024)\end{array}$ & $\begin{array}{l}-0.027 \\
(0.023)\end{array}$ & $\begin{array}{l}0.029 \\
(0.025)\end{array}$ \\
\hline OCOST & $\begin{array}{l}-0.043 \\
(0.074)\end{array}$ & $\begin{array}{l}0.150 * * * \\
(0.052)\end{array}$ & $\begin{array}{l}-0.014 \\
(0.054)\end{array}$ & $\begin{array}{l}0.214 * * * \\
(0.054)\end{array}$ \\
\hline SIZE & $\begin{array}{l}0.000 \\
(0.000)\end{array}$ & $\begin{array}{l}0.000 * * * \\
(0.000)\end{array}$ & $\begin{array}{l}0.000 \\
(0.000)\end{array}$ & $\begin{array}{l}0.000 * * \\
(0.000)\end{array}$ \\
\hline $\mathrm{SIZE}^{\wedge} 2$ & $\begin{array}{l}-0.000 \\
(0.000)\end{array}$ & $\begin{array}{l}-0.000 * * * \\
(0.000)\end{array}$ & $\begin{array}{l}-0.000 \\
(0.000)\end{array}$ & $\begin{array}{l}-0.000 \\
(0.000)\end{array}$ \\
\hline EXPORTER & $\begin{array}{l}-0.006 * * * \\
(0.001)\end{array}$ & $\begin{array}{l}0.000 \\
(0.001)\end{array}$ & $\begin{array}{l}0.001 \\
(0.001)\end{array}$ & $\begin{array}{l}0.004 * * * \\
(0.001)\end{array}$ \\
\hline FOREIGN & $\begin{array}{l}-0.329 * * * \\
(0.089)\end{array}$ & $\begin{array}{l}-0.150^{*} \\
(0.078)\end{array}$ & $\begin{array}{l}0.148 * * \\
(0.063)\end{array}$ & $\begin{array}{l}-0.100 \\
(0.070)\end{array}$ \\
\hline Constant & $\begin{array}{l}0.686 \\
(1.944)\end{array}$ & $\begin{array}{l}-2.275^{*} \\
(1.325)\end{array}$ & $\begin{array}{l}-1.674 \\
(1.369)\end{array}$ & $\begin{array}{l}-1.407 \\
(1.358)\end{array}$ \\
\hline R2 & 0.130 & 0.094 & 0.110 & 0.236 \\
\hline
\end{tabular}

This table displays OLS coefficients and robust standard errors clustered at firm level in parenthesises. *, ** and $* * *$ denote significance levels of 10,5 and $1 \%$, respectively. Columns 1 to 4 show first stage results of a manual IV estimator for the lag of number of competitors (NCOMP), lag of price competition intensity (PRICECOMP), lag of quality competition (QUALCOMP) and lag of technological potential (TECHPOT), where the lag of industry averages serve as instruments and all regressors are lagged. In addition to the displayed coefficients, all estimations include year and industry dummies

\section{References}

Adner, R., \& Levinthal, D. (2001). Demand heterogeneity and technology evolution: Implications for product and process innovations. Management Science, 47(5), 611-628.

Aghion, P., Bloom, N., Blundell, R., Griffith, R., \& Howitt, P. (2005). Competition and innovation: An inverted-U relationship. The Quarterly Journal of Economics, 120(2), 701-728.

Arrow, K. A. (1962). Economic welfare and the allocation of resources to invention. In P. Mirowski \& E.-M. Sent (Eds.), Science bought and sold (pp. 165-180). Chicago: The University of Chicago Press.

Arvanitis, R., \& Stucki, T. (2012). What determines the innovation capability of firm founders? Industrial and Corporate Change. (forthcoming).

Arvanitis, R., Sydow, N., \& Woerter, M. (2008). Is there any impact of university-industry knowledge transfer on innovation and productivity? An empirical analysis based on swiss firm data. Review of Industrial Organization, 32, 77-94.

Aschhof, B., \& Schmidt, T. (2008). Empirical evidence on the success of R\&D cooperation-happy together. Review of Industrial Organisation, 33, 41-62. 
Beise, M., \& Stahl, H. (1999). Public research and industrial innovations in Germany. Research Policy, 28, 397-422.

Belderbos, R., Carree, M., \& Lokshin, B. (2004). Cooperative R\&D and firm performance. Research Policy, 33, 1477-1492.

Beneito, P. (2003). Choosing among alternative technological strategies: an empirical analysis of formal sources of innovation. Research Policy, 32, 693-713.

Beneito, P. (2006). The innovative performance of in-house and contracted R\&D in terms of patents and utility models. Research Policy, 35, 502-517.

Bloom, N., Schankerman, M., \& Van Reenen, J. (2010). Identifying technology spillovers and product market rivalry, draft-version, August 4, 2010.

Boone, J. (2008a). A new way to measure competition. The Economic Journal, 118, 1245-1261.

Boone, J. (2008b). Competition: Theoretical Parameterizations and Empirical Measures. Journal of Institutional and Theoretical Economics, 164, 587-611.

Cassiman, B., \& Veugelers, R. (2002). R\&D cooperation and spillovers: Some empirical evidence from Belgium. American Economic Review, 92(4), 1169-1184.

Cassiman, B., \& Veugelers, R. (2005). R\&D cooperation between firms and universities: Some empirical evidence from Belgian manufacturing. International Journal of Industrial Organisation, 23, 355-379.

Clougherty, J. A., \& Duso, T. (2009). The impact of horizontal mergers on rivals: Gains to being left outside a merger. Journal of Management Studies, 46, 1365-1395.

Cohen, W. M., \& Levinthal, D. A. (1989). Innovation and learning: The two faces of R\&D. Economic Journal, 99, 569-596.

Cohen, W. M., \& Levinthal, D. A. (1990). Absorptive capacity: A new perspective on learning and innovation. Administrative Science Quarterly, 35, 128-152.

Colombo, M. G., Grilli, L., \& Piva, E. (2006). In search of complementary assets: The determinants of alliance formation of high-tech start-ups. Research Policy, 35(1166), 1199.

Eisenhardt, K. M., \& Schoonhoven, C. B. (1996). Resource-based view of strategic alliance formation: Strategic and social effects in entrepreneurial firms. Organization Science, 7, 136-150.

Geroski, P. A. (1990). Innovation, technological opportunity and market structure. Oxford Economic Papers, 42, 586-602.

Gilbert, R. (2006). Looking for Mr. Schumpeter: Where are we in the competition-innovation debate? Innovation Policy and the Economy, 6, 159-215.

Glaister and Buckley. (1996). Strategic motives for international alliance formation. Journal of Management Studies, 33, 301-332.

Greene, W. H. (2003). Econometric analysis (5th ed.). New Jersey: Pearson Education Inc.

Hall, B. H., Link, A. N., \& Scott, J. T. (2001). Barriers inhibiting industry from partnering with universities: Evidence from the advanced technology program. Journal of Technology Transfer, 26, 87-98.

Hayton, J. C., Sehili, S., \& Scarpello, V. (2010). Why do firms join consortial research centers? An empirical examination of firm, industry and environmental antecedents. Journal of Technology Transfer, 35, 494-510.

Hernán, R., Marín, P. L., \& Siotis, G. (2003). An empirical evaluation of the determinants of research joint venture formation. The Journal of Industrial Economics, 51, 75-89.

Jirjahn, U., \& Kraft, K. (2011). Do spillovers stimulate incremental or drastic product innovations? Evidence from German establishment data. Oxford Bulletin of Economics and Statistics, 73(4), 509-538.

Kamien, M. I., Muller, E., \& Zang, I. (1992). Research joint ventures and R\&D cartels. American Economic Review, 82, 1293-1306.

Levin, R. C., Cohen, W. M., \& Mowery, D. C. (1985). R\&D appropriability, opportunity, and market structure: New evidence on some Schumpeterian hypotheses. American Economic Review, 75, $20-24$.

Link, A. N., Paton, D., \& Siegel, D. S. (2002). An analysis of policy initiatives to promote strategic research partnerships. Research Policy, 31, 1459-1466.

Link, A. N., Paton, D., \& Siegel, D. S. (2005). An econometric analysis of trends in research joint venture activity. Managerial Decision Economics, 26, 149-158.

Medda, G., Piga, D., \& Siegel, D. S. (2005). University R\&D and firm productivity: Evidence from Italy. Journal of Technology Transfer, 30, 199-205.

Miotti, L., \& Sachwald, F. (2003). Cooperative R\&D: Why and with whom? An Integrated Framework of Analysis, Research Policy, 32, 1481-1499.

Negassi, S. (2004). R\&D co-operation and innovation a microeconometric study on French firms. Research Policy, 33, 365-384.

Ornaghi, C. (2006). Spillovers in product and process innovation: evidence from manufacturing firms. International Journal of Industrial Organization, 24, 349-380. 
Oxley, J. E., Sampson, R. C., \& Silverman, B. S. (2009). Arms race or détente? How interfirm alliance announcements change the stock market valuation of rivals. Management Science, 55(8), 1321-1337.

Röller, L., Siebert, R., \& Tombak, M. M. (2007). Why firms do or do not form RJVs. The Economic Journal, 117, 1122-1144.

Schumpeter, J. A. (1912). The theory of economic development. Leipzig: Duncker und Humblot.

Schumpeter, J. A. (1942). Capitalism, socialism, and democracy. New York: Harper and Brothers.

Shapiro, C. (2002). Competition policy and innovation, OECD Science, Technology and Industry Working papers, 11.

Teece, D. J. (1992). Competition, cooperation and innovation: Organizational arrangements for regimes of rapid technological progress. Journal of Economic Behavior \& Organization, 18, 1-25.

Tong, T. W., \& Reuer, J. J. (2010). Competitive consequences of interfirm collaboration: How joint ventures shape industry profitability. Journal of International Business Studies, 41, 1056-1073.

Utterback, J. M., \& Abernathy, W. J. (1975). A dynamic model of product and process innovation. OMEGA, The International Journal of Management Science, 3(6), 639-656.

Veugelers, R. (1997). Internal R\&D expenditures and external technology sourcing. Research Policy, 26, 303-315.

Veugelers, R., \& Cassiman, B. (1999). Make and buy in innovation strategies: Evidence from Belgian manufacturing firms. Research Policy, 28, 63-80.

Vives, X. (2008). Innovation and competitive pressure. The Journal of Industrial Economics, 56, 419-469.

Woerter, M. (2011). Driving forces for research and development strategies: An empirical analysis based on firm-level panel data. Economics of Innovation and New Technology, 20(7), 611-636. 